of the awards of the Hague Tribunal in the cases of the Carthage and the Manouba. Part III contains the texts of various important national legislative acts and treatises; part IV contains a number of miscellaneous papers, among others a sketch of the life and services of the late Professor Westlake by Professor Oppenheim of Cambridge; part V contains various "Chroniks" of important happenings during the year 1913 and part VI is devoted to reviews of new books on international law. The volume as a whole comes up fully to the high standard set by the editors in the beginning and it easily ranks as one of the most valuable publications that we have in the field of international law.

\title{
DECISIONS OF STATE COURTS ON POINTS OF PUBLIC LAW
}

Interstate comity. Newport v. Merkel, Kentucky, Dec. 19, 1913. 161 S.W. 549. An act may validly exempt non-resident owners of motor vehicles from registration and the payment of a license fee, if they have complied with a similar law of the state of their residence. Such a statute supersedes an ordinance subjecting non-residents to the requirement.

Operation of constitutional provisions. State v. Brodigan, Nevada, Feb. 28, 1914. 138 Pac. 914. The article of the constitution of Nevada providing for referendum and initiative declares that it shall be selfexecuting. It fails however to impose upon the Secretary of State any duties regarding the filing of referendum petitions for submission of a law to the voters of a county.

Held that provision for such filing should be made by statute and that in the absence of a statutory provision the Secretary of State will not be required by mandamus to file the same.

Legislative Power, Delegation; statewide referendum. Hudspeth v. Swayze, New Jersey, Jan. 23, 1914. 89 Atl. 780. The provision of the so-called chancellor-sheriff jury act, by which its operation is made to depend upon a favorable vote of the people, does not constitute a delegation of legislative power to be exercised directly by the people. It is a perfect piece of legislation, the effect of which is conditioned upon the happening of the contingency.

Since the popular vote was affirmative, it is not necessary to consider, whether the power to reject would have constituted an unconstitutional delegation of the power to repeal. 
While the trend of authority is against the validity of such delegation, the affirmative view is supported by such eminent authority, that the legislature had the right to form its own judgment.

Legislative Power, Delegation: local option. Ex parte Francis, Texas, Jan. and Feb. 1914. 165 S. W. 147. A local option provision in a statute making its operation in any county dependent upon the result of an election therein, does not violate the provisions of the constitution, restricting the power to suspend laws to the legislature, and forbidding the exercise of such power by any other body.

Very full discussion and long dissenting opinion.

Delegation of Pouer. Abbott v. State. Supreme Court of Mississippi. Dec. 22, 1913. 63 So. 667. An act giving a state live stock sanitary board "plenary power to deal with all contagious and infectious diseases of animals as in the opinion of the board may be prevented, controlled and eradicated," is not invalid as a delegation of legislative power.

Departments of Government. Constitutional Powers of Corporation Commission. State v. Tucson Gas, etc., Co. Supreme Court of Arizona, Feb. 18, 1914. 138 Pac. 781. Under the constitution the corporation commission has full power to fix classifications, rates and charger of public service corporations and the legislature has therefore no powes to require such corporations to sell their products by meter measurement.

Judicial Power. State v. Summers, South Dakota, Dec. 30, 1913. 144 N.W. 730. An act providing for referendum on municipal ordinances upheld.

"In our judgment: the time has come when courts should decline the task of attempting by construction to add to defective legislation, or to eliminate or limit provisions which work public or private injury. They should interpret the law as it is written, and not otherwise."

Due Process-right of appeal. Cullins v. Williams, Kentucky, Nov. 21, 1913. 160 S.W. 733. An act permitting the commitment of dependent children fails to provide for a right of appeal. This does not invalidate the statute since the right of appeal is purely a matter of legislative discretion. However in proper cases parties aggrieved may resort to the writ of habeas corpus or of prohibition. 
Due Process-summary proceedings against defaulting tax collectors. Gaulden v. Wright, Georgia, Nov. 14, 1913. 79 S.E. 1125. Civil Code, Sec. 1187, allows the Comptroller General to issue execution against a tax collector who fails to settle his accounts with him, without providing for notice and hearing. Held unconstitutional.

A similar proceeding had been sustained by the U. S. Supreme Court in Murray's Lessee v. Hoboken Land and Improvement Co. 18 How. 272.

Due Process-statutory presumptions in criminal cases. State v. Russell, North Carolina, Nov. 10, 1913. 80 S.E.66. A statute makes it an offense to have in possession a certain amount of liquor for purpose of sale and declares that possession of the amount shall be prima facie evidence that it is kept for sale. Held that this does not destroy the presumption of innocence; the jury must, in order to convict, be convinced of the guilt of the accused beyond a reasonable doubt.

Equality-classification. Ex parte Lewinsky. Florida, Nov. 11, 1913. 63 So. 577. A statute regulating the sale of intoxicating liquors may validly exempt hotels having 100 rooms or more. The court suggests that in very large hotels the bar is a mere incident, and the hotel management will, as a matter of self protection, see to it that it is properly conducted.

Equal rights: monopoly: union labor clause in public contracts. Wright v. Hoctor, Nebraska, Feb. 13, 1914. 145 N.W. 704. A union labor clause in a contract for public work invalidates the contract, and its performance will be restrained by injunction.

Church and State; use of school house for religious meetings. State v. Dilley. Nebraska, March 13, 1914. 145 N.W. 999. A school district board will not be compelled by mandamus to close the school house to occasional use for religious meetings not interfering with the school work.

Police power-Minimum wage legislation. Stettler v. O'Ilara, Oregon, March 17, 1914. 139 Pac. 743. The minimum wage act is a constitutional exercise of the police power; it does not delegate legislative power. In view of the provisions for hearing, it is not unconstitutional to make the commission's findings of fact conclusive. 
Police Power-Gift enterprises. State v. Sperry \& Hutchinson Co. 94 Neb. 785; Dec. 24, 1913. An act prohibiting the business of giving and redeeming trading stamps is an unreasonable interference with lawful business, and invalid under the State Bill of Rights and the Fourteenth Amendment.

Police Power-Construction of Statute. People v. Guiton. New York Dec. 16, 1913. 210 N. Y. 1. The oleomargarine law of New York forbids imitation of butter either by the selection of artificial coloring matter not being an essential ingredient, for the sole purpose of producing the imitated color, or the selection of ingredients with the predetermination and purpose of producing the imitated color; but it does not prohibit a semblance to butter not resulting from imitation, but from a selection of ingredients dissociated from the intention to imitate. Manufacturers need not choose ingredients deliberately so as to avoid the shade of color which is that of butter.

Taxation and court fees. Malin v. La Moure County, North Dakota, Feb. 14, 1914. 145 N. W. 582. Probate fee graduated according to the size of estate should be judged as taxes; as taxes they are invalid because they are in addition to the uniform tax to which all property in the state is subject. They are not inheritance taxes because not. limited to the net value of the estate. 